Accelerator Department

BROOKHAVEN NATIONAI IABORATORY

Associated Universities, Inc.

Upton, L.I., N.Y.

AGS DIVISION TECHNICAL NOTE

No. 11

Th. Sluyters

February 4, 1966

PROGRESS REPORT (4) CONCERNING HIGH GRADIENT COLUMN

The duoplasmatron in the present preinjector continues to perform reliable with an averaged beam current of around $75 \mathrm{~mA}$ after the column. Harold Wroe thinks that the cathode attachment will soon be in its final state.

Harold took a bunch of emittance measurements at $750 \mathrm{keV}$ for various conditions and geometries of the extractor region of the source; he is still in the process of evaluating his results. An interesting feature anyhow, is that with a smal1 expansion cup ( $\phi=1 \frac{1}{2} \mathrm{~mm}$ instead of $4 \mathrm{~mm}$ ), an important higher brilliance $\left(\sim 8 \mathrm{x} 10^{8} \mathrm{~mA} / \mathrm{cm}^{2} \mathrm{rad}^{2}\right)$ could be obtained, maintaining the same column output current. To determine the maximum column output (which is now $115 \mathrm{~mA}$ ), he plans to install a solenoid with large inner diameter just behind the collumn.

The duoplasmatron with large cup has been installed in the rig; unfortunately oscillations ( $\pm 15 \%$ of the peak value) have been observed on the output, but none on the discharge current, which was inherent in previous results with the old source. The only difference was the anode exit holê (0.025-in.), which could not be made larger due to the absence of cooling around the leak. A quick check of some larger cup sizes on Harold's rig proved that the size of the exit hole was indeed important. A cathode air-vacuum lock is in the workshop.

\title{
Accelerating Column
}

A column has been assembled with one set of voltage dividers (bananas) and spark gaps. Vacuum has been obtained as 1 ow as $6 \times 10^{-7} \mathrm{~mm}$ (meter indication). 
Vincent Kovarik's RDI power supply is now running more or less reliably at $600 \mathrm{kV}$. The rectifiers are still a weak part; 1ife tests with modified Machlett tubes will start soon. The HV bushing (an unshielded Sames cable) and the connections with the measuring dome stood $600 \mathrm{kV}$ during short trials. HV tests of dome and column are in progress.

The vital parts for the inner structure and assembling are ready; however, Bill Schneider has to modify the adaptor of the source, so that the anode can reach the extractor at closer distances than originally planned. His measuring box should be ready as soon as possible, (ultimate date - middle of March!).

Final cabling by Bob Lockey's people should be finished soon. A $150 \mathrm{kV}$ power supply will be installed in the equipment dome; it can be used either to increase the voltage up to $750 \mathrm{kV}$ or as a standyby in case of lower limitation in RDI, bushings, etc.

After some modifications of Rugy Damn's solenoid, the theoretical magnetic field has been obtained; significant asymmetries ( 5\% of axis field value) within an effective core of 2-in. were observed over short distances on both ends of the solenoid. An improved version with twice the number of turns per unit length than the original one will diminish the above asymmetries to a smaller figure.

Dick Amari's $750 \mathrm{kV}$ automatic emittance unit is more or less designed.

The $50 \mathrm{MeV}$ emittance unit is in the assembling status. There is some lack of technicians in this building period.

Attached you will find a time schedule of the HV tests, etc.

cc : R. Amari

R. Damm

V. Kovarik.

R. Larson

R. Lockey

$\nabla$. Racanie11o

W. Schneider

A. van Steenbergen

H. Wroe

TS/ah 
TIME SCHEDULE

\begin{tabular}{|c|c|c|c|c|c|}
\hline & $\begin{array}{l}\text { Feb. } \\
7-11\end{array}$ & $\begin{array}{l}\text { Feb } \\
14-18\end{array}$ & $\begin{array}{l}\text { Feb } \\
2-1-25\end{array}$ & $\begin{array}{l}\text { Feb.-March } \\
28-4\end{array}$ & $\begin{array}{l}\text { March } \\
7-11\end{array}$ \\
\hline RDI - dome - column HV tests & & & $\ldots$ & . & \\
\hline Installation Ti-electrodes & & & & . & .. \\
\hline HV tests column and electrodes & & & & & \\
\hline $\begin{array}{l}\text { Installation ion source, emittance box, } \\
\text { be1t, freon cooling, solenoid, second } \\
\text { set of voltage dividers }\end{array}$ & & & & & \\
\hline
\end{tabular}

